\title{
SuRVey OF THE LAW OF Professional ReSPONSIBILITY
}

\author{
G. Michael WiTTE* \\ INTRODUCTION
}

Lawyers are guardians of free speech. However, in the practice of their art, there are many restrictions on a lawyer's own speech and communications. ${ }^{1}$ They cannot propound false statements to a tribunal. ${ }^{2}$ They cannot breach their client's confidences. ${ }^{3}$ Their advertising messages have restrictions. ${ }^{4}$ Their communication with a represented third party is restricted. ${ }^{5}$ Some states, including Indiana, prohibit discriminatory speech in a professional capacity. ${ }^{6}$ Public comment about a pending matter carries restriction. ${ }^{7}$ This Article will address several $2014^{8}$ discipline matters that dealt with improper lawyer comments to a judge, about a judge, or in the presence of a judge.

Ex parte communication with a judge about a pending matter, without the participation of the opposing party, is a staple on the checklist of prohibited lawyer action. ${ }^{9}$ This should be common knowledge among lawyers. However, are lawyer comments about a judge under the scrutiny of the Rules of Professional Conduct? If one were to gather together a group of lawyers, then the conversation would likely turn to comments about a judge or a judicial ruling. The comments about the judge might even be caustic. Should lawyers be fearful that the exaggerated criticism in that setting can lead to discipline? The simple answer is no, but there are other settings where critical speech about a judge can attract ethical scrutiny. Indiana Professional Conduct Rule 8.2(a) governs lawyer comments about the integrity of a judge. ${ }^{10}$ In fiscal year 2014, lawyer speech critical of a judge served as a basis for Indiana Supreme Court rulings in two professional conduct cases. ${ }^{11}$

* Executive Secretary, Indiana Supreme Court Disciplinary Commission; J.D. 1982, Indiana University Robert H. McKinney School of Law. The opinions expressed herein are solely those of the author and do not represent a statement of law or policy by the Indiana Supreme Court, its staff or attendant agencies or organizations. The author thanks law clerk Chelsea Faver for her research assistance in the creation of this work.

1. See generally Ind. Prof'L Conduct R. (2015).

2. Ind. PROF'l CONDUCT R. 3.3(a) (2015).

3. IND. PROF'L CONDUCT R. 1.6 (2015).

4. Ind. PRof'L Conduct R. 7.2 (2015).

5. Ind. PRof'L CONDUCT R. 4.2 (2015).

6. Ind. PROF'L CONDUCT R. 8.4(g) (2015).

7. IND. PRof'l CONDUCT R. 3.6(a) (2015).

8. The 2014 fiscal year of the Disciplinary Commission runs from July 1, 2013 to June 30, 2014.

9. IND. PROF'L CONDUCT R. 3.5(b) (2015).

10. IND. PROF'L CONDUCT R. 8.2(a) (2015).

11. In re Ogden, 10 N.E.3d 499 (Ind. 2014); In re Dixon, 994 N.E.2d 1129 (Ind. 2013). 


\section{IN RE DIXON ${ }^{12}$}

In 2009, the announcement that the Commencement ceremony speaker and honorary degree recipient would be President Barrack Obama prompted pro-life demonstrations at the University of Notre Dame. ${ }^{13}$ More than eighty demonstrators were arrested and eighty-five cases were consolidated into one case in the St. Joseph County Superior Court. ${ }^{14}$ The case was assigned to Judge Jenny Pitts Manier, whose husband was a tenured and retired professor at Notre Dame. ${ }^{15}$ Attorney Thomas Dixon represented the eighty-five arrestees. ${ }^{16}$

Judge Manier previously presided over a prior pro-life protest related case in 2007, and attorney Dixon represented a person who was denied intervenor status in that matter. ${ }^{17}$ That representation, along with Judge Manier's spouse's relation to Notre Dame, served as a basis for critical commentary by attorney Dixon in his Motion for Change of Judge, Motion to Reconsider, and two supporting affidavits he filed on behalf of the eighty-five arrestees. ${ }^{18}$ His submitted comments included the following:

Statement A: Such large scale litigation, and the results therefrom, could adversely impact Notre Dame's bottom line, which in turn could have a negative impact on Notre Dame's current and future employees. It is in Professor Manier's interest to see that this does not occur. In short, Judge Manier and her husband are simply too intertwined with, and invested in, the University of Notre Dame and its mission to be allowed to preside over these cases. ${ }^{19}$

Statement B: Judge Manier's inability to admit the intellectual and political (in the sense of policy setting) consanguinity between her husband's career mission and Notre Dame's current mission, calls into profound question her ability to navigate the waters of defendants' legal defenses related to their contractual rights to be where they were when they were arrested. ${ }^{20}$

Statement C: Judge Manier's ruling applying the injunction to Mrs. Kendall can be explained in only one of two ways: either Judge Manier

12. Dixon, 994 N.E.2d at 1129.

13. Id. at 1131.

14. Id.; see State v. All Consolidated Cause Defendants, No. 71D01-0905-CM-03246.

15. Dixon, 994 N.E.2d at 1131.

16. Id.

17. Id.; see Kendall v. City of South Bend, No. 71D07-0602-PL-52.

18. Dixon, 994 N.E.2d at 1131.

19. Id. at 1132 (citations omitted) (quoting Verified Compl. at para. 2-4, In re Dixon, No. 71S00-1104-DI-196) (internal quotation marks omitted). The court emphasized the particular text that the discipline hearing officer concluded was in violation of Indiana Professional Conduct Rule $8.2(\mathrm{a})$.

20. Id. at 1132-33 (emphasis in original). 
did not understand the privity requirement of Trial Rule 65, or she did not feel duty bound to apply the rule because she was biased in favor of the abortuary. ${ }^{21}$

Statement D: Judge Manier's refusal to allow Marsh into the case, when she knew Mrs. Kendall wanted out of the case, demonstrates to me that she was willing to ignore the applicable legal standards in order to move the case in a direction that negatively affected Marsh's legal rights without giving him the ability, as required by Trial Rule 24, to have a voice in the process or defend the same. ${ }^{22}$

Attorney Dixon was charged with attorney misconduct by violating Indiana Professional Conduct Rule 8.2(a). ${ }^{23}$ The Rule reads as follows:

(a) A lawyer shall not make a statement that the lawyer knows to be false or with reckless disregard as to its truth or falsity concerning the qualifications or integrity of a judge, adjudicatory officer or public legal officer, or of a candidate for election or appointment to judicial or legal office.

(b) A lawyer who is a candidate for judicial office shall comply with the applicable provisions of the Code of Judicial Conduct. ${ }^{24}$

The rationale for this rule rests upon the assumption that the general public's trust and confidence in the fair administration of justice relies significantly on the public views expressed by lawyers familiar with a judge's performance. ${ }^{25}$ False statements by a lawyer can unfairly undermine that trust and confidence. ${ }^{26}$

It was the position of the Indiana Disciplinary Commission ("the Commission") that the four statements questioned the judge's legal ability and independence, and asserted that the judge was following a pre-determined personal agenda rather than following the law. ${ }^{27}$ The Commission asserted that the attorney recklessly stated this hyperbole without any facts to support the

21. Id. at 1133 (emphasis in original).

22. Id. (emphasis in original).

23. Id.

24. IND. PROF'L CONDUCT R. 8.2 (2015).

25. Comment [1] to IND. Prof'L CONDUCT R. 8.2 provides:

Assessments by lawyers are relied on in evaluating the professional or personal fitness of persons being considered for election or appointment to judicial office and to public legal offices, such as attorney general, prosecuting attorney and public defender. Expressing honest and candid opinions on such matters contributes to improving the administration of justice. Conversely, false statements by a lawyer can unfairly undermine public confidence in the administration of justice.

26. Id.

27. Dixon, 994 N.E.2d at 1133. 
accusations. $^{28}$

The hearing officer in this case concluded that Statement A did not violate Rule 8.2(a), and the Commission did not contest that conclusion in the Indiana Supreme Court. ${ }^{29}$ Regarding Statements B, C, and D, the court first had to address what standard of review would be applied to the statements - subjective or objective. ${ }^{30}$ The case of New York Times Co. v. Sullivan addressed these standards in the context of a public official seeking redress for defamation. ${ }^{31}$ The United States Supreme Court ruled that First Amendment protection for speech and press called for a subjective standard when a public official brought a defamation action. ${ }^{32}$ The standard required a showing of actual malice and a sufficiency of evidence that permits "the conclusion that the defendant in fact entertained serious doubts as to the truth of his publication," and that there was "a high degree of awareness of probable falsity." 33

The Indiana Supreme Court had to decide if it should apply this high standard of subjectivity in lawyer discipline cases where a lawyer is accused of making recklessly false statements about a judge, or if it should apply an objective standard tied to the reasonable lawyer test in lawyer discipline cases.

The Indiana Supreme Court conducted a survey of case law $^{34}$ and determined that the objective standard, adopted by a majority of states, would apply to Indiana's Rule 8.2(a). ${ }^{35}$ The court noted that the absence of a factual basis for an attorney's scurrilous comment about a judge was "the heart of an objective

28. Id.

29. Id.

30. Id. at 1133-36.

31. Id. at 1134 (citing N.Y. Times Co. v. Sullivan, 376 U.S. 254 (1964)).

32. Id. (citing N.Y. Times, 376 U.S. at 279-80).

33. Id. (quoting Harte-Hanks Commn's, Inc. v. Connaughton, 491 U.S. 657, 688 (1989)).

34. Id. at 1134-36. The court cited In re Terry, where an attorney was disbarred after the court found he engaged in two counts of misconduct and had a prior suspension from his judicial duties. 394 N.E.2d 94, 96 (Ind. 1979). The attorney had made false accusations against the Indiana Supreme Court Justice who authored an opinion suspending the attorney from his position as judge, and the attorney asserted to public officials that the motivation for the Justice to suspend the attorney was that the Justice conspired with others to conceal alleged criminal activity. Id. at 95 . The second count of misconduct and prior suspension are not related for purposes of this discussion. The court also cited In re Atanga, where an attorney was suspended for multiple rule violations after he failed to appear at a hearing and made statements to a reporter. 636 N.E. $2 \mathrm{~d}$ 1253, 1254 (Ind. 1994). The attorney was asked by the reporter about a local judge and was quoted in a local paper as saying he believed the judge was "ignorant, insecure, and a racist . . and accus[ed him] of being motivated by political ambition, being part of the prosecution, and engaging in judicial tyranny." Id. at 1256. Finally, the court also cited In re Wilkins, where an appellate attorney was suspended after he stated in a brief that an Indiana Court of Appeals opinion left him wondering "whether the Court of Appeals was determined to find for [opposing party], and then said whatever was necessary to reach that conclusion (regardless of whether the facts or the law supported its decision)." 777 N.E.2d 714, 715-76 (Ind. 2002).

35. Dixon, 994 N.E.2d at 1136. 
test. ${ }^{\text {36 }}$ First Amendment societal interests in public discussion of public issues must be balanced against the public's confidence in a competent and impartial judiciary. ${ }^{37}$ The court concluded that the damage to public trust in the judiciary outweighed free speech protection for recklessly false statements about a judge. ${ }^{38}$

After determining the standard of review, the court applied the standard to Dixon's comments about Judge Manier. ${ }^{39}$ The court noted that the comments were not just made in the course of litigation. ${ }^{40}$ Rather, they were allegations of actual bias and prejudice, albeit not necessarily supported with facts, asserted to seek a judge's recusal. ${ }^{41}$ The allegations were in a Motion for Change of Judge in a criminal case, Motion for Reconsideration, and supporting affidavits. ${ }^{42}$ In Indiana, a Change of Judge Motion in a criminal case requires a showing of actual bias and prejudice ${ }^{43}$ - a high wall to scale in meeting that burden of proof. ${ }^{44}$ The court recognized that a showing of actual bias affirmatively requires allegations of personal bias and prejudice by the judge. ${ }^{45}$ A lawyer who seeks a change of judge on behalf of a criminal defendant is forced to make unpopular allegations. ${ }^{46}$ In that particular instance, it was "good faith professional advocacy" ${ }^{47}$ on behalf of a client. A lawyer facing a Rule 8.2(a) violation in this situation will be held to the least restrictive limits of that rule. ${ }^{48}$

The court contrasted Dixon's statements against those made in an appellate brief in the case In re Wilkins. ${ }^{49}$ Wilkins was an appellate practitioner who represented an insurance company in an appeal of an adverse verdict from the court of appeals. ${ }^{50}$ In a brief supporting a petition to transfer to the Indiana Supreme Court, Wilkins wrote in a footnote that the court of appeals opinion was "so factually and legally inaccurate that one is left to wonder whether the Court

\section{Id. at 1135 .}

37. Id. at 1136 .

38. Id.

39. Id. at 1137.

40. Id.

41. Id.

42. Id.

43. IND. CRIM. RULE 12(b) provides in part:

[i]n felony and misdemeanor cases, the state or defendant may request a change of judge for bias or prejudice. The party shall timely file an affidavit that the judge has a personal bias or prejudice against the state or defendant. The affidavit shall state the facts and the reasons for the belief that such bias or prejudice exists, and shall be accompanied by a certificate form the attorney of record that the attorney in good faith believes that the historical facts recited in the affidavit are true.

44. Dixon, 994 N.E.2d at 1138.

45. Id.

46. $I d$.

47. $I d$.

48. Id. at 1139.

49. In re Wilkins, 777 N.E.2d 714 (Ind. 2002).

50. Id. 
of Appeals was determined to find for" the opposing party and then "said whatever was necessary to reach that conclusion (regardless of whether the facts or the law supported its decision)." 51

The court determined that Wilkins suggested an improper motivation for the judges' ruling. ${ }^{52}$ Also, Wilkins' speculation about the judges was based only upon the fact that his client received an unfavorable decision. ${ }^{53}$ The court distinguished Dixon's allegations because they were not based upon improper motivation and they were based on assertions of fact that are required for a change of judge motion. ${ }^{54}$ For these reasons, the court concluded that attorney Dixon did not violate Rule 8.2(a). ${ }^{55}$

Lawyers should not be fearful that any criticism of a judge will become the basis of an ethics investigation. Making a recklessly false comment about a judge to a social guest or to a colleague at work is not the focus of Rule 8.2(a). ${ }^{56}$ The Dixon matter and other Indiana $\operatorname{cases}^{57}$ show that false and vituperative comments about a judge's integrity that play out in a public forum or in the public record of the court are the purview of Rule 8.2(a). ${ }^{58}$

\section{IN RE OGDEN $N^{59}$}

If the venue of a Rule 8.2(a) violation is a public setting, can a false comment about a judge in correspondence to a person who is outside the immediate sphere of pending litigation be viewed as within a public setting? That was the situation in another 2014 discipline case involving Rule 8.2(a). ${ }^{60}$ In re Ogden arose from a challenge to the administration of a decedent's estate. ${ }^{61}$ Attorney Ogden's client was a child of the decedent. ${ }^{62}$ The client was adverse to the other heirs, his

51. Id. at 715-16.

52. Id at 717 .

53. Id.

54. In re Dixon, 994 N.E.2d 1129, 1139 (Ind. 2013).

55. Id.

56. See id.

57. See Wilkins, 777 N.E.2d at 714 (finding misconduct when an attorney stated in a brief that an Indiana Court of Appeals opinion left him wondering whether the court was determined to find for opposing party and accused the court of using whatever means necessary to reach that outcome); In re Litz, 721 N.E.2d 258 (Ind. 1999) (finding misconduct when an attorney allowed a letter defending his client, criticizing a prosecutor's decisions, and revealing that his client passed a lie detector test to be published in several local newspapers); In re Reed, 716 N.E.2d 426 (Ind. 1999) (finding misconduct when a prosecuting attorney gave a press interview to reporters where he made several disparaging statements about a judge's qualifications and integrity).

58. See Wilkins, 777 N.E.2d at 714 .

59. 10 N.E.3d 499 (Ind. 2014).

60. See id.

61. Id. at 500 .

62. Id. 
siblings, one of whom was the estate's executor. ${ }^{63}$

Ogden was critical of several decisions by the trial court, including: the executor serving without bond, the estate being unsupervised, and the approval of the final accounting. ${ }^{64} \mathrm{He}$ also asserted that the judge was a personal friend of the executor and was therefore biased, that the judge allowed the executor to dissipate the estate's assets, and that the judge committed malfeasance and misconduct. ${ }^{65}$ All of these accusations were contained in correspondence sent to the estate's attorney and copied to the decedent's ex-wife. ${ }^{66}$ The ex-wife was the mother of the decedent's children but was not an heir or devisee of the estate and was not a party to the legal proceedings. ${ }^{67}$

Ogden was charged with a single count violation of Rule 8.2(a) ${ }^{68}$ supported by four separate statements in the single communication. The statements were categorized as follows:

(1) He alleged that [the judge] committed malfeasance in the initial stages of the administration of the Estate by allowing it to be opened as an unsupervised estate, by appointing a personal representative with a conflict of interest, and by not requiring the posting of a bond.

(2) He alleged that [the judge] committed malfeasance in the subsequent administration of the Estate by, among other things, permitting misconduct by the personal representative, which resulted in dissipation of Estate assets.

(3) He alleged that [the judge] should have recused himself from the case because he was a friend of some members of the family, including the personal representative, and thus had a disqualifying conflict of interest.

(4) He alleged that [the judge] was unqualified as a judge and he engaged in judicial misconduct in presiding over the Estate. ${ }^{69}$

One might think that the correspondence was private and was protected private speech. Indeed, Ogden thought so. ${ }^{70}$ The Commission countered that Ogden took the message public when he copied the non-party, non-heir ex-spouse of the decedent. ${ }^{71}$ However, the court never addressed this jurisdictional issue. ${ }^{72}$ Since the court eventually concluded that Ogden violated Rule 8.2(a), it can only be assumed that the court did not think the facts supported this angle of private

63. Id.

64. $I d$.

65. Id.

66. Id.

67. See id.

68. Id. Ogden was also charged with a second rule violation relating to an ex parte letter communication arising from an independent, unrelated investigation.

69. Id. (citations omitted).

70. Affirmative Defense at 1-3, In re Ogden, No. 49S00-1303-DI-183.

71. See id.

72. See Ogden, 10 N.E.3d at 502. 
free speech being addressed. ${ }^{73}$ But the court did address the applicability of free speech to category (2). ${ }^{74}$

Ogden's representation of his client began sometime after the estate was opened. ${ }^{75}$ A second judge had taken over the case prior to Ogden entering his appearance. $^{76}$ The original decisions to appoint the executor, allow an unsupervised estate, and waive an executor's bond were all made by the first judge in the case. ${ }^{77}$ This was easily determined from examination of both the docket sheet and the case file in the probate court. ${ }^{78}$ Nevertheless, Ogden's criticisms in category (1) were aimed at the second judge in the case even though that judge was not the decision maker for those results. ${ }^{79}$ The statements in category (1) were obviously false, let alone recklessly false, and served as the basis for Ogden's Rule 8.2(a) discipline. ${ }^{80}$

Regarding the category (2) statements the court ruled that these fell into Ogden's broad First Amendment rights which allow public criticism of judicial decisions and was not a violation of Rule $8.2(\mathrm{a}){ }^{81}$

Regarding category (3), the court determined that it was the client who made the assertions about the judge being a family acquaintance and that Ogden was entitled to believe his client. ${ }^{82}$ This ruling raises the question of whether the court was imposing a subjective standard only eight months after it established the objective standard in the Dixon $^{83}$ decision. In fact, the court re-affirmed the objective reasonable basis standard in the Ogden decision, ${ }^{84}$ but the distinction for the category (3) statement seems contradictory to an objective standard.

Did Ogden have a duty to at least investigate the allegation of the judge's relationship to the decedent's family and the alleged improper influence on the judge? The truth or falsity of this assertion should be easily discoverable. It is fairly certain that a reasonable attorney would first attempt to establish facts to support the client's accusation of the judge's bias before taking the accusation public. ${ }^{85}$ Stated another way, would a reasonable attorney publicly assert that a judge is being improperly influenced without first vetting the client's allegations? The failure to vet the accusation suggests a reckless disregard of the truth about

73. Id.

74. Id. at 501 .

75. Id. at 500 .

76. Id.

77. $I d$.

78. Id. at 501 .

79. Id.

80. Id.

81. Id.

82. Id.

83. In re Dixon, 994 N.E.2d 1129, 1136 (Ind. 2013).

84. Ogden, 10 N.E.3d at 501.

85. See, e.g., In re Reed, 716 N.E.2d 426 (Ind. 1999) (issuing of public reprimand warranted where attorney failed to verify the accuracy of his opinion before making statements alleging a judge's bias). 
the judge's integrity. ${ }^{86}$ The improper influence accusation can negatively impact the public's trust and confidence in the judicial system. ${ }^{87}$

Stating that an attorney is protected because one must believe the client's assertion implies that a discipline charge would require a subjective burden of proof in that situation. Bar counsel would have to prove that the lawyer knew the assertion was not true but still chose to publicize the client's false statement about the judge being unlawfully influenced to reach a decision. Hiding behind a shield of blind reliance on a client's false accusation about a judge suggests a subjective standard for discipline to attach. ${ }^{88}$

An interesting extension of this argument is whether a lawyer can knowingly choose to not know the truth of a statement. In other words, is a lawyer who chooses to not know the truth of a client's statement making a knowing misrepresentation to a third person resulting in a violation of Rule $4.1(\mathrm{a})^{89}$ rather than Rule 8.2(a)? ${ }^{90}$ Rule 8.2(a) is reserved to false statements about a judge's professional ability or integrity. ${ }^{91}$ Rule 4.1(a) applies to any materially false statements to third persons. ${ }^{92}$ Specifically, subsection (a) reads: "In the course of representing a client a lawyer shall not knowingly: (a) make a false statement of material fact or law to a third person; . . .."93

This issue was discussed in In re Broderick. ${ }^{94}$ Broderick represented his twenty-one year old son in an Indiana criminal matter. ${ }^{95}$ The matter was disposed of with a deferred prosecution agreement. ${ }^{96}$ The son and father both signed the agreement acknowledging that the son had no prior arrests. ${ }^{97}$ This was a false statement. ${ }^{98}$ Two years earlier, Broderick represented his son in a criminal matter in Florida. ${ }^{99}$

Broderick claimed in his defense that he did not read the deferred

86. Id. at 428 .

87. Id. at 429 .

88. But see In re Denney, 983 N.E.2d 571 (2013) (A motion to disqualify a judge was based on the judge's personal bias against Denney's client. The motion was supported with an affidavit from the client and a purported transcript of recorded conversation between the client and others. The transcript included irrelevant topics such as the judge's alleged sexual relationships and the character of the judge's former wife. However, Denney was not charged with a violation of Rule 8.2(a). Instead the publicly filed affidavit was the basis for a violation of both Rules 4.4(a) and 8.4(d).).

89. IND. PROF'L CONDUCT R. 4.1(a) (2015).

90. IND. PROF'L CONDUCT R. 8.2(a) (2015).

91. Id.

92. IND. PROF'L CONDUCT R. 4.1(a) (2015).

93. $I d$.

94. 929 N.E.2d 199 (Ind. 2010).

95. Id.

96. Id.

97. Id.

98. Id. at 200.

99. Id. at 199 . 
prosecution agreement before signing it, relying instead on a summary of the agreement presented by an administrator of the prosecutor's office, as well as his own experience in other counties where no such statement regarding prior arrests was included. ${ }^{100}$

The court found that Broderick violated Rule 4.1(a) by knowing that he was unaware of what representations he was making in a legal proceeding. ${ }^{101}$ Broderick intentionally chose to be ignorant of a likely falsehood in the deferral agreement document. ${ }^{102}$ Therefore, his misrepresentation about his son's prior arrest was a knowing act. ${ }^{103}$

Regarding the Ogden case, the respondent was not charged with a violation of Rule 4.1(a), as the facts appear to fit more properly into a Rule 8.2(a) analysis. ${ }^{104}$ But in hindsight after the court's ruling, a Rule 4.1(a) violation might have been a proper consideration.

Finally, the court determined that the category (4) statements were "more in the nature of opinions as opposed to statements of fact." 105 However, since the matter was charged as a single count with four separate violations occurring in the communication, the proof of the statement identified in category (1) was sufficient to render discipline against Ogden. ${ }^{106}$

\section{IN RE BARKER ${ }^{107}$}

A lawyer's intemperate written speech in a letter to opposing counsel in a pending matter served as the basis for discipline in In re Barker. ${ }^{108}$ The client representation involved a father's alleged difficulty in the exercise of his parenting time with his child. ${ }^{109}$ The text of the letter, with the emphasis in the original, was as follows:

[Father] told me this week that he has only seen his baby ... one day all year. Your client doesn't understand what laws and court orders mean I guess. Probably because she's an illegal alien to begin with.

I want you to repeat to her in whatever language she understands that we'll be demanding she be put in JAIL for contempt of court.

I'm filing a copy of this letter with the Court to document the seriousness of this problem. ${ }^{110}$

\footnotetext{
100. Id.

101. Id.

102. Id.

103. Id.

104. In re Ogden, 10 N.E.3d 499, 500 (Ind. 2014).

105. Id. at 501 .

106. Id. at 502 .

107. 993 N.E.2d 1138 (Ind. 2013).

108. Id.

109. Id. at 1139.

110. Id. (emphasis in original) (citations omitted).
} 
Barker did send a copy of the letter to the presiding judge in the case. ${ }^{111}$ This fact possibly comes into play in the sanction imposed in this case and will be discussed later.

Indiana recognizes discriminatory bias or prejudice as a basis for misconduct. ${ }^{12}$ Specifically, Professional Conduct Rule 8.4(g) serves as the prohibition against such conduct. ${ }^{113}$ It reads as follows:

It is professional misconduct for a lawyer to ...

(g) engage in conduct, in a professional capacity, manifesting, by words or conduct, bias or prejudice based upon race, gender, religion, national origin, disability, sexual orientation, age, socioeconomic status, or similar factors. Legitimate advocacy respecting the foregoing factors does not violate this subsection. A trial judge's finding that preemptory challenges were exercised on a discriminatory basis does not alone establish a violation of this Rule. ${ }^{114}$

Legitimate advocacy is an exception to this standard. ${ }^{115}$ If a discriminatory bias or prejudice is an issue of fact or law in the underlying case, then references to that conduct would be legitimate in light of the underlying matter. ${ }^{116}$ It would be difficult to grant legitimate advocacy protection to a gratuitous insertion of prejudicial language into the litigation dialogue. ${ }^{117}$

In In re McCarthy, the dispute arose in a real estate title search. ${ }^{118}$ The agent representing the real estate seller had his secretary send an email to the lawyer demanding a meeting for all involved in the dispute. ${ }^{119}$ The lawyer sent a reply email to the agent's secretary that included the offensive insult "nigger." 120 The Indiana Supreme Court rejected the lawyer's defense that the use of the pejorative term was a historic reference to slavery in light of the real estate agent making demands upon the lawyer's service. ${ }^{121}$ The court did not find there was a connection to legitimate advocacy. ${ }^{122}$

However, it might be implied that Barker's comments were legitimate

111. Id.

112. InD. PROF'L CONDUCT R. 8.4(g) (2015).

113. Id.

114. Id.

115. Id.

116. Id.

117. $I d$.

118. In re McCarthy 938 N.E.2d 698 (Ind. 2010).

119. $I d$.

120. The full text of the email stated: "I know you must do your bosses [sic] bidding at his direction, but I am here to tell you that I am neither you [sic] or his nigger. You do not tell me what to do. You ask. If you ever act like that again, it will be the last time I give any thought to your existence and your boss will have to talk to me. Do we understand each other?" Id.

121. Id.

122. Id. 
advocacy. If the child's mother was in fact an illegal alien, could there be a concern that she might take the child across international borders and outside the reach of the father and the trial court? Maybe, if the underlying facts in the parenting time action supported such an issue was in play, then further analysis would be required. But such were not the facts of the Barker case. ${ }^{123}$ And, could not a legal alien, a person with dual United States citizenship, or even a citizen with no international ties pose a similar threat so that the illegal status has no legitimate reference to the prejudicial comment? The court rejected Barker's argument that the discriminatory language was used in the course of legitimate advocacy. ${ }^{124}$

If Barker's prejudicial comments were not legitimate advocacy, then what were their purposes? That can be answered with a second rule violation that was imposed against the lawyer in this matter. ${ }^{125}$ Lawyers owe ethical duties to nonclients and third persons. ${ }^{126}$ These duties include truthfulness in statements to third persons, ${ }^{127}$ communications with persons represented by counsel, ${ }^{128}$ and dealings on behalf of a client with a person unrepresented by counsel. ${ }^{129}$ Lawyers must also respect the rights of third persons. ${ }^{130}$ Professional Conduct Rule 4.4(a) governs this duty and it states: “(a) In representing a client, a lawyer shall not use means that have no substantial purpose other than to embarrass, delay, or burden a third person, or use methods of obtaining evidence that violate the legal rights of such a person."131

The official comment to Rule 4.4(a) does not specifically identify actions that might "embarrass, delay, or burden a third person." Some instances of application of this part of the rule include: (1) An attorney removing a client's children from their school by intimidating a school secretary so she could speak to the children concerning child abuse allegations, ${ }^{132}$ (2) an attorney serving subpoenas on a third party before litigation had commenced when the attorney had no authority to do so, ${ }^{133}$ and (3) an attorney filing a lawsuit alleging

123. In re Barker, 993 N.E.2d 1138, 1139 (Ind. 2013).

124. Id.

125. $I d$.

126. See generally IND. PROF'L CONDUCT R. 4 (2015).

127. Ind. PROF'L CONDUCT R. 4.1 (2015).

128. Ind. PROF'L CONDUCT R. 4.2 (2015).

129. IND. PROF'L CONDUCT R. 4.3 (2015).

130. Ind. PROF'L CONDUCT R. 4.4 (2015).

131. Id.

132. In re Hemphill, 971 N.E.2d 665, 666 (Ind. 2012) (The court found that an attorney concerned that her client's children were being abused by their mother's boyfriend intimidated a school secretary into releasing the children to her so she could keep them for several hours and speak to them privately before an upcoming hearing. The court found that the stated purpose of the attorney could have been accomplished by more appropriate means and had no substantial purpose other than to burden the secretary and the mother.).

133. In re Anonymous, 896 N.E.2d 916, 917 (Ind. 2008) (The attorney served a third person with three subpoenas on three separate occasions commanding the third person to appear with 
defamation against the person who submitted a grievance about him to the Disciplinary Commission. ${ }^{134}$

In the Barker matter, the court found that his comments violated Rule 4.4(a). ${ }^{135}$ It can be reasonably implied that since the prejudicial comments were not legitimate advocacy, then they served no purpose other than to embarrass or burden the child's mother. ${ }^{136}$

As noted earlier, Barker sent a copy of the letter to the trial judge in the matter. ${ }^{137}$ This might have had an impact on his sanction. ${ }^{138}$ Barker received a thirty-day suspension of his law license. ${ }^{139}$ Several other cases involving violations of Rule $8.4(\mathrm{~g})$ with no aggravating factors have resulted only in public reprimands. ${ }^{140}$

A judge has similar anti-bias and prejudice duties within the Code of Judicial Conduct. ${ }^{141}$ Canon 2, Rule 2.3 imposes these duties on a judge. ${ }^{142}$ Judicial Conduct Rule 2.3(C) also requires a judge to patrol any discriminatory behavior of lawyers while appearing before the court. ${ }^{143}$ Specifically, Rule 2.3(C) states:

(C) A judge shall require lawyers in proceedings before the court to refrain from manifesting bias or prejudice, or engaging in harassment, based upon attributes including but not limited to race, sex, gender, religion, national origin, ethnicity, disability, age, sexual orientation, marital status, socioeconomic status, or political affiliation, against

specified documents for an examination under oath pursuant to Indiana Trial Rules 45(B), 34(C), and $45(\mathrm{~A})(2)$. The attorney did not have authority to use subpoenas before litigation had commenced.).

134. In re Kinnard, 2 N.E.3d 1267, 1268 (Ind. 2014) (The attorney filed a lawsuit against a woman who had submitted a grievance to the Disciplinary Commission concerning that attorney's conduct during a paternity and child support case. The attorney alleged in his defamation action that the statements in the grievance were false and made with malice intended to cause harm to him. However, the assertions of fact in the grievance were true and the attorney's lawsuit was unfounded in both fact and law.).

135. In re Barker, 993 N.E.2d 1138, 1139 (Ind. 2013).

136. Id.

137. Id.

138. See infra notes $145-53$ and accompanying text.

139. Barker, 993 N.E.2d at 1139.

140. See In re Kelley, 925 N.E.2d 1279 (Ind. 2010) (believing that a company representative on the phone had a feminine-sounding voice, asking the representative whether he was "gay" or "sweet"); In re Campiti, 905 N.E.2d 408 (Ind. 2009) (sanctioning of an attorney with a public reprimand, even though he had two aggravating factors, after the attorney made repeated references to the fact that a mother was not a United States citizen during a child support modification hearing); In re Thomsen, 837 N.E.2d 1011 (Ind. 2005) (referring to a man as a "black male" and "the black guy" in a petition for custody and during a hearing when the man's race was irrelevant).

141. See InD. Judicial CONDUCT R. 2.3.

142. Id.

143. InD. JUdiCIAL CONDUCT R. 2.3(C). 
parties, witnesses, lawyers, or others. ${ }^{144}$

By sending a copy of the intemperate letter to the presiding judge, and therefore, the court, it became a part of the public record. ${ }^{145}$ Since it related to a specific cause of action pending before the court, it is expected that the letter should be placed in the court file and an entry made on the case chronological summary-the docket sheet. ${ }^{146}$

It is reasonable to infer that the presiding judge had a duty under Judicial Conduct Rule 2.3(C) to patrol this filing of the letter and take action with the lawyer. ${ }^{147}$ A judge in this position should take corrective action to eliminate any notion that the trial court was permissive of the biased, prejudiced or harassing event occurring. ${ }^{148}$ Maybe this is the reason that Barker received a thirty-day license suspension rather than the public reprimand that other violators of Professional Conduct Rule 8.4(g) have received. ${ }^{149}$

$$
\text { IV. IN RE ALEXANDER }{ }^{150}
$$

A fourth discipline case in the past year dealt with a lawyer's advocacy comments in the presence of a judge and jury. ${ }^{151}$ The following excerpts come

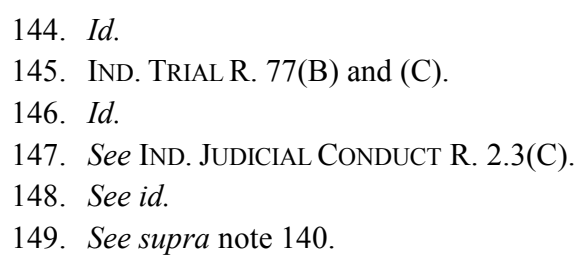

150. 10 N.E.3d 1241 (Ind. 2014). The timeline of the underlying representation and the misconduct prosecution was quite lengthy. The representation of the client began in 1998. The tort action was tried in 2003. In 2006, the Indiana Supreme Court overturned the trial court verdict. See Outback Steakhouse of Fla., Inc. v. Markley, 856 N.E.2d 65 (Ind. 2006). The discipline investigation began in 2006 after the Indiana Supreme Court's ruling in the trial appeal. In 2008, Alexander was charged with bribery and the ethics investigation was placed on hold. Alexander was acquitted of the charge in 2009. See State v. Alexander, No. 18C03-0802-FC-0003. In 2010, Alexander sued the United States Government for malicious prosecution, but the United States District Court for the Southern District of Indiana dismissed his claim. See Alexander v. United States, No. 1:11-cv-00762-SEB-DKL. In 2013, the United States Seventh Circuit Court of Appeals reinstated Alexander's claim. See Alexander v. United States, 721 F.3d 418 (7th Cir. 2013). The ethics investigation resumed with the filing of a misconduct Verified Complaint January 2, 2013. The ethics case was tried on February 28, 2014 and was disposed with a ruling from the Indiana Supreme Court on June 18, 2014.

151. In re Alexander, 10 N.E.3d 1241 (Ind. 2014). Alexander was also disciplined on a second count of misconduct regarding an employee in his law office who had resigned from the bar. This count was unrelated to the count that serves as the basis of discussion for this Article. Resignation is a misconduct discipline status. A resigned lawyer is not permitted to "maintain a presence or occupy an office where the practice of law is conducted." IND. ADMISSION \& DISCIPLINE R. 23, § 26(d). Alexander was found to have violated Indiana Professional Conduct Rule 5.5(a) for assisting in the unauthorized practice of law and Indiana Professional Conduct Rule 
from Alexander's closing argument to the jury on behalf of the plaintiff.

Statement 1: "My clients didn't want anybody punished. Good thing, because this is the perfect case for punitive damages . ..."152

Statement 2: "And then once in a career this happens, I can tell you because I've been doing this thirty (30) years this fall." 153

Statement 3: "That girl has more courage than any witness I've ever seen. She didn't care what happened to her. She didn't care of the consequences. She had to tell the truth, and she did."154

Statement 4: "This man seated right here is one of the most severely injured people I've ever represented. And maybe number one if it wasn't for who's seated to his left (Lisa)." 155

Statement 5: "And if you remember his testimony, he's one (1) of the more credible witnesses I've ever seen", and later continued, "All they have talked to you about is Joe Arvin, how he is a liar, which I resent." 156 Statement 6: "And here's a story for you, but this isn't part of the evidence. I once saw a lady at the Waffle House on New Year's Eve pick up a catsup bottle, I was watching her across the restaurant, and drink out of it thinking it was a beer because she was so intoxicated. . . But we're supposed to believe that this guy who was so drunk couldn't tell (the difference between Crown and Coke and plain Coke). I don't think so." 157

Restrictions are placed upon a lawyer's advocacy speech during trial. ${ }^{158}$ Professional Conduct Rule 3.4(e) prohibits a lawyer from alluding to irrelevant matters or matters not supported by evidence, asserting personal knowledge of facts, vouching for witness credibility or party culpability, or vouching for guilt or innocence of a criminally accused. ${ }^{159}$ The purpose behind this rule is to ensure a fair playing field for the trial participants. ${ }^{160}$ The trial process is adversarial,

8.4(a) for knowingly assisting another person to violate the Rules of Professional Conduct.

152. Verified Compl. I 25, In re Alexander, No. 18S00-1301-DI-1.

153. Id. $₫ 26$.

154. Id. ๆ 27.

155. Id. $ๆ 28$.

156. Id. $₫ 29$.

157. Id. $₫ 30$.

158. IND. PROF'L CONDUCT R. 3.4(e) (2015).

159. Rule 3.4(e) provides, in pertinent part, that a lawyer shall not in trial, allude to any matter that the lawyer does not reasonably believe is relevant or that will not be supported by admissible evidence, assert personal knowledge of facts in issue except when testifying as a witness, or state a personal opinion as to the justness of a cause, the credibility of a witness, the culpability of a civil litigant or the guilt or innocence of an accused; .... .

IND. PROF'L CONDUCT R. 3.4(e) (2015).

160. See id. (titled "Fairness to Opposing Party and Counsel). 
but the playing field should be level. ${ }^{161}$ Therefore, tactics that might be interpreted as improper witness influencing are prohibited or restricted. ${ }^{162}$

The various statements by Alexander might appear singularly to be trivial. Also, they might be nullified by a jury instruction that directs the jurors not to accept any statements of the lawyers as evidence. However, the repeated nature of injecting his personal beliefs and vouching for witness credibility take the record of this closing argument beyond trivial. ${ }^{163}$

Although not the focus of this particular Article, Alexander also engaged in discovery violations that led to his client's favorable verdict being overturned by the Indiana Supreme Court. ${ }^{164}$ The discovery violations and the improper statements to the jury served as the basis for discipline in Count Two of the Complaint. ${ }^{165}$

Alexander received a stiff rebuke from the court in the 2006 Outback Steakhouse decision stating: "Indiana discovery rules are specifically designed to avoid surprise and . . . trial by ambush. ... We have consistently rejected a 'gaming view' of the litigation process." 166 Could the court likewise have viewed the repeated closing argument faux pas as a continuation of the "gaming" attitude of Alexander? That will never be known, but the court got a second opportunity to address the closing argument in the related 2014 discipline matter. ${ }^{167}$

Regarding Statement 1, the parties had agreed that plaintiff (Alexander's client) would withdraw a claim for punitive damages if the defendant would not raise comparative fault as a basis for the plaintiff's co-liability. ${ }^{168}$ Despite this agreement, Alexander tried to inflame the jury with reference to punitive actions in his closing argument. ${ }^{169}$

Alexander inserted his personal knowledge into the argument via Statements 2 , 4, and $6 .{ }^{170}$ He also vouched for witness credibility in Statements 3 and $5 .{ }^{171}$ And, he vouched for the culpability of the opposing party in Statements 2 and $6 .{ }^{172}$ Legal counsel is not a witness for a client. ${ }^{173}$ Legal counsel is an advocate for the client. ${ }^{174}$ Advocacy does not allow for the lawyer to become personally

161. See Ind. Prof'L Conduct R. 3.4(e), cmt. 1 (2015).

162. See generally Ind. PRof'L CONDUCT R. 3.4 (2015).

163. Verified Compl. ๆๆ 25-30, In re Alexander, No. 18S00-1301-DI-1. See In re Alexander, 10 N.E.3d 1241, 1242 (Ind. 2014) (finding a violation of Rule 3.4(c) and 3.4(e)).

164. Alexander, 10 N.E.3d at 1241-42. See generally Outback Steakhouse of Fla., Inc. v. Markley, 856 N.E.2d 65 (Ind. 2006) (overturning of Alexander's client's verdict).

165. Alexander, 10 N.E.3d at 1241-42.

166. Outback Steakhouse, 856 N.E.2d at 76.

167. Alexander, 10 N.E.3d at 1242.

168. Outback Steakhouse, 856 N.E.2d at 79.

169. Id.; see also Alexander, 10 N.E.3d at 1242.

170. Verified Compl. $₫ \uparrow$ 26, 28, 30, In re Alexander, No. 18S00-1301-DI-1

171. Id. ๆๆ 27, 29.

172. Id. $₫ \uparrow 26,30$.

173. See generally Ind. Prof'L Conduct R. 3.4 (2015).

174. See generally id. 
involved. ${ }^{175}$ Additionally, Statements 2, 3, 4 and 6 allude to facts that were not supported by admissible evidence. ${ }^{176}$ Each of these statements served as a basis for a violation of Professional Conduct Rule 3.4(e) as well as Rule 8.4(d) - engaging in conduct that was prejudicial to the administration of justice. ${ }^{177}$ Alexander received a sixty-day suspension of his law license for his misconduct. ${ }^{178}$

What if the statements had been made in opening statement rather than closing argument? Would Rule 3.4(e) still be applicable? The answer would be "yes" as to the vouching statements and personal knowledge statements. ${ }^{179}$ However, determining whether the opening statement alluded to facts not supported by admissible evidence, one would have to wait until the close of the evidence to make that assessment. ${ }^{180}$ Such was the case in In re Baker. ${ }^{181}$

Baker's client stood trial for murder where the victim had been missing for several years. ${ }^{182}$ During his opening statement, Baker stated that search dogs were sent out shortly after the victim's disappearance. ${ }^{183}$ He stated that a dog "alerted" at the home of B.H. but the dog was called off. ${ }^{184}$ Baker attempted to set up reasonable doubt at the opening of the trial, but these statements were false. ${ }^{185}$ Baker should have known that no evidence would be admitted at trial to support them. ${ }^{186}$ Baker's opening statement served as a basis for a violation of Professional Conduct Rule 3.4(e) by alluding to facts that would not later be supported by admissible evidence at trial. ${ }^{187}$

\section{CONCLUSION}

Whether a lawyer is speaking to a judge, about a judge, or in advocacy before a judge, the Rules of Professional Conduct establish the boundaries of how to behave or perform in those various instances. The opinions expressed by lawyers play an important role in shaping how the general public views the administration of justice. The court has recognized how false statements publicly declared by a lawyer can strongly undermine this trust and confidence. Demonstrating bias or prejudice outside of the realm of legitimate advocacy or engaging in unfair

175. See generally id.

176. Verified Compl. 9 ๆ 26-28, 30, In re Alexander, No. 18S00-1301-DI-1.

177. In re Alexander, 10 N.E.3d 1241, 1243 (Ind. 2014).

178. Id.

179. See Ind. Prof'L Conduct R. 3.4(e) (2015) (“in trial, allude to any matter that ...") (emphasis added).

180. Id.

181. 955 N.E.2d 729 (Ind. 2011).

182. Id.

183. Id.

184. Id.

185. Id.

186. Id.

187. Id. at 729-30. 
trial tactics have also been viewed as not upholding the integrity of the legal profession. However, lawyers should not take these decisions to mean that any unpopular comment will become the basis of a disciplinary investigation. Rather, lawyers should be mindful that assertions in a professional capacity should maintain the integrity of the legal profession. 